Article

\title{
Core Elements towards Circularity: Evidence from the European Countries
}

\author{
Olga Lingaitienè $(\mathbb{D})$ and Aurelija Burinskienè * \\ Faculty of Business Management, Vilnius Gediminas Technical University, LT-10223 Vilnius, Lithuania; \\ olga.lingaitiene@vilniustech.lt \\ * Correspondence: aurelija.burinskiene@vilniustech.lt
}

Citation: Lingaitienè, O.;

Burinskienè, A. Core Elements towards Circularity: Evidence from the European Countries. Sustainability 2021, 13, 8742. https://doi.org/ $10.3390 /$ su13168742

Academic Editor: Elena Cristina Rada

Received: 3 July 2021

Accepted: 31 July 2021

Published: 5 August 2021

Publisher's Note: MDPI stays neutral with regard to jurisdictional claims in published maps and institutional affiliations.

Copyright: (c) 2021 by the authors. Licensee MDPI, Basel, Switzerland. This article is an open access article distributed under the terms and conditions of the Creative Commons Attribution (CC BY) license (https:// creativecommons.org/licenses/by/ $4.0 /)$.

\begin{abstract}
In this paper, the authors identified key elements important for circularity. The primary goal of circularity is to eliminate waste and prove the constant use of resources. In the paper, we classified studies according to circular approaches and stated which of them get the highest attention. Further, we identified the principal elements, grouped them into four categories important for circularity, and presented scientific works dedicated to each of the above-mentioned categories. Further on, several core elements from the first category were investigated, aiming to connect different waste streams and provide a regression model. Finally, the methodological part reviewed the correlation between various types of waste and their recycling and selected suitable ones for developing a new panel regression model. The empirical research was delivered for the 27 European Union countries during the period between 2000 and 2019. We indicate that the recycling rate of municipal waste impacts the increase of recycling biowaste the same calendar year. The increase of recycling of municipal waste by one per cent means the increase of the recycling of biowaste by 0.6 per cent.
\end{abstract}

Keywords: circularity; waste streams; circular approaches; regression equation

\section{Introduction}

Excessive use of natural resources, essential for economic growth and development, has harmed the environment while making these resources rarer and more expensive [1,2]. Therefore, it is not difficult to see why the idea of a circularity, which offers new ways to create a more sustainable economic growth model, is taking hold around the world.

An early approach towards practical sustainability was envisioned and demonstrated as saving resources, preventing waste, and the extension of product shelf life [3-6]. However, the recycling agenda requires the industry to restructure its processes towards sustainability. Case examples are proving the interlink between recycling and sustainability [7-10]. These examples summarise and demonstrate successful implementation by some companies from the production industry, like Hewlett Packard and Low carbon industrial manufacturing park (LOCI-MAP), etc., and studies investigating the effect on environmental and socio-economic conditions sustainable development [11-13].

A perfect circularity with $100 \%$ efficient material use cannot exist due to physical and practical limitations in material recycling [14-17]:

- Material turnover requires energy costs and impacts on the environment. These effects can sometimes outweigh the effects of primary production. In any case, the impact of energy use should not go beyond environmental protection.

- Materials cannot be required to be recycled or reused in the long term. For example, steel in buildings cannot be reused for many years. Therefore, material demand cannot be met.

- Demand for most products is growing as the economy grows. Unfortunately, even the perfect material turnover is not enough to meet the growing demand. 
- Material turnover includes inherent processing losses. Materials can also lose quality or be contaminated. Therefore, even with stable demand, additional raw materials are needed.

- The supply of recycled raw materials is not in line with demand. In addition, due to technological changes or lack thereof, substances that can only be obtained from pure extraction may be preferred.

These constraints mean that recycling and recycling efficiency alone is not enough to achieve sustainable yields. The more efficient use of materials can also have repercussions, as cheaper raw materials could lower prices and stimulate higher consumption $[13,18]$. Where higher consumption requires energy, production has an impact on the environment $[19,20]$.

The efficient use of resources could help to protect the environment but may hamper economic growth or vice versa. Therefore, modelling will help to define these boundaries [21]

Compared to the linear scheme, circularity is a more complex system [22-24]. Complexity arises from material stocks, return flows and management in different countries, resource planning, logistics and recycling management, coordination of multi-level network activities, and physical and information flow between network partners [25-28].

This study consists of three parts-the review of scientific studies and identifying main elements important for circularity are presented at the beginning of the study. Further on, the methodology of the article is presented. Following the methodology, the authors revised core elements relevant for circularity by applying regression analysis. Seeking practical investigations, the paper revised data from European Union countries. Based on the analysis, the authors constructed a set of regression equations to describe circularity. Finally, discussion and conclusion sections were provided.

\section{Literature Review on Circularity}

The changing economic environment (the programme of the European Commission's Communication "Creating a circular economy. A Europe without waste") and changes in the business organisation processes themselves lead to changes in the fields of materials extraction, production, marketing, and recycling [29,30]. Keeping this in mind, many companies are modernising and reorganising traditional supply chains and moving from "linear" to "circular", thus reducing the consumption of material resources and energy, as well as the amount of waste generated [31-33].

The emergence of circularity is a natural evolutionary process. Still, new challenges are now being encountered, such as the seamless (non-fragmented) arrangement and aggregation of relevant functional activities over time to ensure a continuous and closed cycle of "raw material-product-waste" movements [34]. In the long run, circularity protects the world's dependence on natural resources. It delivers benefits to society by absorbing emissions and waste through increased material circulation and staying the natural environment's limits [35-37].

The cycles of extraction, production, and consumption of products are shortened, which results in a faster cycle of material flows, including the collection, sorting, and recycling of used products [38,39]. The research theme responds to the European Union (EU) research priorities in Horizon 2020, which emphasises the need to increase the lifespan of goods, reuse materials, recover resources using harmful technologies, and focus on the duration of resources over-exploitation [40]. The private sector and industry, which have a public commitment to ensure that recycled materials account for a certain proportion of products placed on the market, will play a key role in shaping demand. The private sector will have to implement the most appropriate solutions given the product's extended life cycle [41-43].

The circular scheme links traditional linear processes with product return processes involving product recovery, product recycling, dismantling, and reuse of recycled products [44]. The statement "recyclable" means that the materials can be reused. However, this reuse can be applied to just about anything, from converting used plastics to new containers 
we see on the roadside or burning. Thus, "recycling" is a very broad term covering fewer desirable forms of reuse, such as substandard standards and even incineration [4,45,46]. The components and materials are used for enhancing maintenance, reuse, remanufacture, and recycle.

Manufacturers talking about tank design say something more specific. They say that new containers can be used from used container materials or that the material is suitable for similar purposes [47]. Incineration and low-quality adaptation are not possible. These manufacturers are paving the way to circularity. According to the authors [48-50], the optimised use of resources is reached by having the circularity of products.

Therefore, increasing recycling rates is vital to reach circularity. The European Commission is setting new targets on waste management-to increase the share of municipal waste for recycling to $70 \%$ and prepare packaging waste for recycling up to $80 \%$. In this context, the European Commission (EC) has set a 50\% recycling target for all the plastic packaging waste collected by 2025 and $55 \%$ by $2030[5,50]$. The waste management hierarchy indicates the order of priority for waste reduction and management. The goal of the waste management hierarchy is to maximise the products' practical benefits and generate as little waste as possible. The specified target delivers some advantages; it can help prevent greenhouse gas emissions, reduce pollution, save energy, save resources, create jobs, and encourage green technologies.

Reducing the amount of waste generated is a top priority under the Waste Hierarchy set out in the Waste Framework Directive (Article 4), which sets out priorities from prevention, preparation for reuse, recycling, and energy use to environmentally sound disposal, in landfills. In addition, the Law on Waste Management of the Republic of Lithuania establishes the order of priorities applied in waste prevention and management, which is shown in Figure 1.

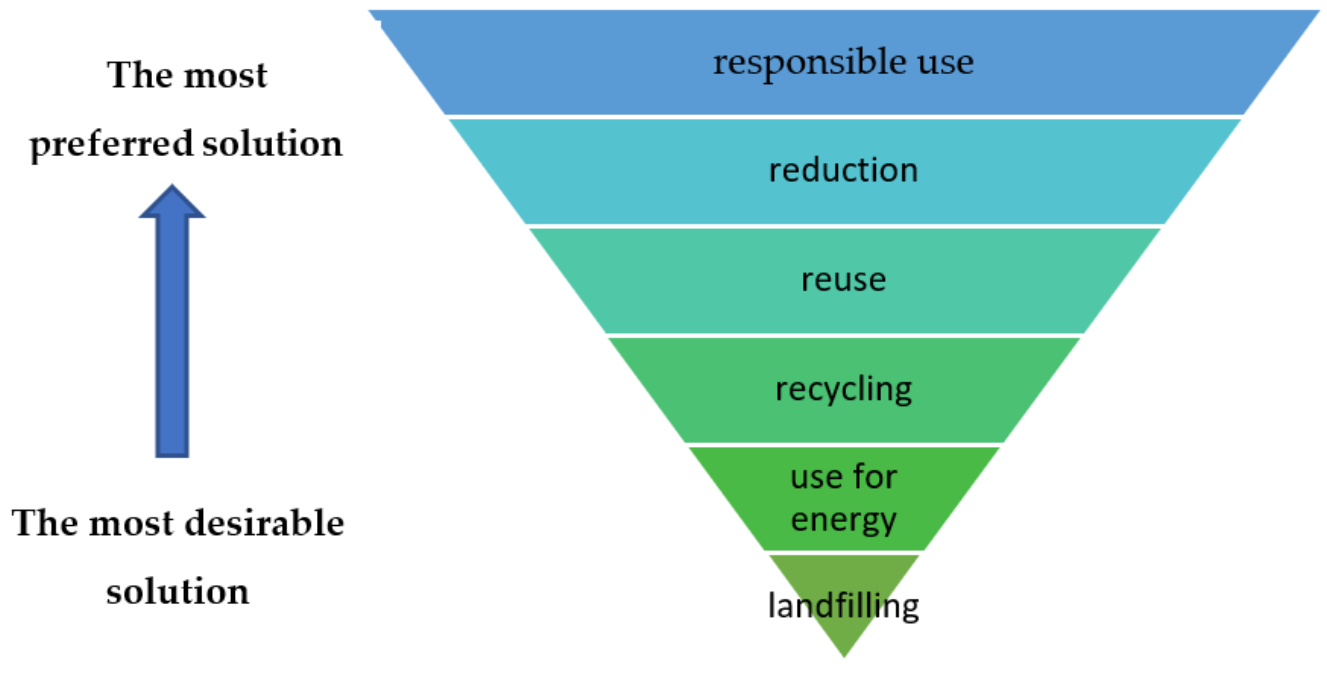

Figure 1. Waste management hierarchy.

The order of priority for waste prevention and management is applied considering the general principles of environmental protection - precaution and sustainability, technical feasibility and economic viability, protection of resources, and overall environmental and public health and economic and social impact.

When products are recycled, repaired, or reused, employment is generated, and when waste from one process is used as an input into others, efficiency and productivity gains are achieved [51]. Therefore, following the hierarchy of priority, this paper focuses on recycling.

It should be noted that the circular economy and the $100 \%$ efficient use of materials also have some financial implications. 
- Energy consumption, which is required for the circulation of substances has an impact on the environment. It is important that the impact of energy consumption does not exceed environmental limits.

- Materials may not be suitable for recycling or reuse. Accordingly, demand cannot be met by using secondary resources alone.

- The circulation of materials alone is not enough to meet growing demand. Along with economic growth, demand for most products is also growing.

- Material turnover can be lost due to lost material quality or contamination. Even with stable demand, additional materials are needed.

- The supply of recycled raw materials does not meet demand. Technological change is important to ensure a balance between supply and demand [52].

Savings of resources depend on how quickly products are collected from consumers, reach recycling sites, and are processed. The shorter duration of the processes also leads to a lower need for material (and natural) resources [19,21,52].

Products and services are rethought in implementing circular solutions based on durability, recyclability, reusability, repair, replacement, renewal, upgrading, and reduced use of materials $[6,31]$. Companies need to apply these principles to avoid waste, increase resource productivity, and decouple growth from natural resource consumption [37,42].

Circularity contributes by increasing resource efficiency and reducing environmental impact [53-55]. This can be achieved by applying or enabling one or more of the following nine circular economies " $R$ "strategies or principles, referred to as the $9 R s$, in line with the main circular approaches, which were first mentioned by the European Commission in 2006 and consisted of reuse (R3), recycle (R8) and recover (R9). Later on, due to high critics, more circular approaches were presented [52].

R-strategy is sometimes treated even as part of the definition of circular economy, which is the recovery of energy from waste and residues. It is recognised that from the point of view of waste management. Energy recovery is preferable to landfilling following the principle of the waste hierarchy from an ecological point of view. In addition, energy recovery from organic waste and renewable residues, including the production of fuels from them, can significantly contribute to climate protection by reducing the consumption of fossil fuels.

Within these 9R strategies, the categorisation system calls for assessments of resource efficiency gains and evaluations of activities' impacts on a lifecycle basis to demonstrate their substantial contributions to the circular economy.

The authors revised the literature, classified the studies according to these approaches (R0-R9), and mentioned them in Table 1. In this case, 22 different combinations covering different circular approaches in 65 studies were indicated. Most authors focus on the 8th combination, which includes 7R: reduce (R2), reuse (R3), repair (R4), refurbish (R5), remanufacture (R6), recycle (R8), and recover (R9). All circular approaches are indicated under the 2nd combination, which is provided by seven studies.

According to the study, some circular approaches get greater attention and some of them lower attention. Most of the authors focus on recycle (R8), reduce (R2), and re-cover (R9) in their studies. In contrast, rethink (R1), repurpose (R7), and refuse (R0) circular approaches get the lowest attention among authors. To achieve circularity, a higher focus is required on R7, which belongs to the end-of-life extend approach. 
Table 1. The classification of studies according to circular approaches.

\begin{tabular}{|c|c|c|c|c|c|c|c|c|c|c|c|}
\hline \multirow[b]{3}{*}{ No } & \multirow[b]{3}{*}{ Authors } & \multicolumn{10}{|c|}{ Circular Approaches } \\
\hline & & \multicolumn{3}{|c|}{ Smarter Production } & \multicolumn{5}{|c|}{ End-of-Life Extension } & \multicolumn{2}{|c|}{$\begin{array}{l}\text { Application } \\
\text { of Materials }\end{array}$} \\
\hline & & 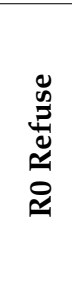 & 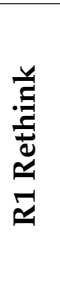 & 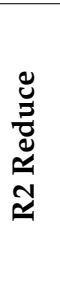 & 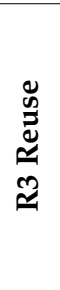 & 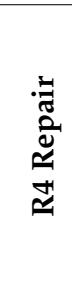 & 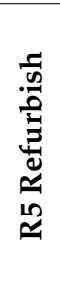 & 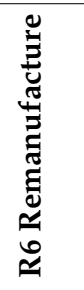 & 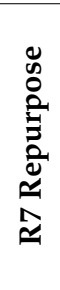 & 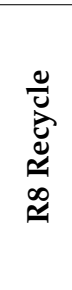 & 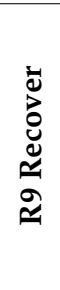 \\
\hline 1. & {$[3,6,14,29,36,43,50,55]$} & & & $x$ & $x$ & & & & & $x$ & $x$ \\
\hline 2. & {$[9,20,24,35,56]$} & $x$ & $x$ & $x$ & $x$ & $x$ & $x$ & $x$ & $x$ & $\mathrm{x}$ & $x$ \\
\hline 3. & {$[17,55]$} & & & $x$ & $x$ & $x$ & $x$ & $x$ & $x$ & $x$ & $x$ \\
\hline 4. & {$[22,48,49,54]$} & & & $x$ & $x$ & & & $x$ & & $x$ & $x$ \\
\hline 5. & {$[21,56]$} & & & $x$ & $\mathrm{x}$ & $\mathrm{x}$ & $x$ & & & $\mathrm{x}$ & $\mathrm{x}$ \\
\hline 6. & [57] & & & $\mathrm{x}$ & $x$ & $\mathrm{x}$ & & $x$ & & $\mathrm{x}$ & $\mathrm{x}$ \\
\hline 7. & {$[10,13,16]$} & & & $x$ & $x$ & $x$ & & & & $x$ & $x$ \\
\hline 8. & {$[7,12,15,18,34,40-42,44,48,51,58]$} & & & $x$ & $x$ & $x$ & $x$ & $\mathrm{x}$ & & $\mathrm{x}$ & $x$ \\
\hline 9. & [19] & & $x$ & $\mathrm{x}$ & $\mathrm{x}$ & $x$ & $\mathrm{x}$ & & & $x$ & \\
\hline 10. & [53] & & & $x$ & $x$ & & $\mathrm{x}$ & & $x$ & $x$ & $x$ \\
\hline 11. & [26] & & & $x$ & & $x$ & & $x$ & & $x$ & $x$ \\
\hline 12. & [27] & & & $x$ & $x$ & $x$ & & & $x$ & $x$ & $x$ \\
\hline 13. & [37] & & & $x$ & $x$ & & $x$ & $x$ & & $x$ & $x$ \\
\hline 14. & [23] & & $x$ & $x$ & $x$ & $x$ & & & & $x$ & $x$ \\
\hline 15. & [38] & & $x$ & $x$ & & $x$ & & & & $x$ & $x$ \\
\hline 16. & [39] & & & $x$ & & & & & & $x$ & $x$ \\
\hline 17. & [28] & & $x$ & $x$ & $x$ & & $x$ & & & $x$ & $x$ \\
\hline 18. & [25] & & $x$ & $x$ & $x$ & $x$ & $x$ & $x$ & & $x$ & $x$ \\
\hline 19. & [59] & & & $x$ & $x$ & $x$ & & & & $x$ & \\
\hline 20. & {$[5,30]$} & & & & $x$ & & & & & $x$ & $x$ \\
\hline 21. & [45] & & $x$ & $x$ & & & $x$ & & & $x$ & $x$ \\
\hline 22. & [60] & & & $x$ & & & & & & $x$ & \\
\hline
\end{tabular}

\section{Core Elements Important for Circularity}

To develop a literature review of circularity, we reviewed the dominant elements. The academic literature provides a comprehensive overview [56-58]. The authors indicated key elements mentioned under the literature review and grouped them into four main categories: waste minimisation, resource recovery, material circularity, and general topics. These categories are selected as representing a high circularity level. For example, general topics cover best practices for delivering value following environmental and social aspects and new business models supporting circularity. The other three categories (i.e., waste minimisation, resource recovery, and material circularity) represent circularity with efficient material use. A longer period could help reach a faster circulation cycle for materials from consumption back to production. 
The first type, waste minimisation, is examined by different authors according to the types of the policy package. It is particularly important that packagers are aligned with strategic economic and industrial policy, as the industrial waste sector is one of those who dictates change from linearity to circularity $[59,60]$.

Forty-eight authors examine basic waste management, applying typical policy measures such as basic provision for public service management of wastes through landfilling or burning. Fourteen authors describe the characteristic of waste hierarchy applied to typical policy instruments, a fast link between waste management and resource use, as the implementation of it. In many areas, progress has been noted mainly in recycling industrial and organic waste $[61,62]$. The authors emphasise that companies that want to reduce municipal waste must focus on consumers and forms of consumption [62,63]. For example, to reuse, reduce, and recycle, we must effectively promote the need to change certain consumer behaviour [19] and to have a substantial waste reduction through prevention, reduction, and recycling $[27,34,52,64]$.

The second type, resource recovery, is promoted by the United Nations and the Organization for Economic Co-operation and Development [64]. Alhawari et al. performed a literature review of a double loop regeneration system that focuses on the efficient and effective use of ecosystem resources, which is beneficial optimisation of environmental and economic activities.

The third type, the material circularity, considers recycled content in the product together with the waste (linear flow) and usefulness of the product (expressed over a lifetime) $[24,65,66]$. Garcés-Ayerbe et al. and Moraga et al. [23,35] make a point of change in the concept of end-of-life by the life cycle of restoration and closed-loop products. They want to eliminate waste, maintain the value of products and materials, promote their use of renewable energy, and remove toxic chemicals. In current production and consumption practices, the "end of life" is being replaced by reducing, reusing, and recycling processes in producing, distributing, and consuming products and materials.

The fourth type covers general topics, which include circular business models and value-added creation. A circular business model revises the logic of how a company generates value for its customers by reducing the environmental effect. The circular business model is different from a linear one and follows the logic of designing products without waste and pollution, storing used products and materials, and restoring natural systems.

Following the above-stated studies, the authors identified main categories closely interlinked with circularity (Table 2). Each category includes elements identified in studies and is significant for circularity. The first category focuses on waste, waste streams, and waste reduction and reflects the waste priority hierarchy presented in Figure 1. The second category concentrates on resource recovery. Resource recovery is the process which uses waste as a resource for the development of value-added products. The third category covers the circularity of materials. The use of circulating material, also known as turnover rate, is defined as the ratio of the circular use of materials to the total consumption of materials. A higher value of circulation rate means that more secondary materials replace the primary raw materials. This helps to reduce the impact on the environment during the extraction of introductory material.

Finally, the last category indicates very general topics, i.e., other topics displaying circular direction and promoting the transformation from linear to circular.

All four of these categories are the key for circularity, which begins from waste-related questions that discuss the treatment of waste indicated as a resource. Later, the resource is recovered and used to its full potential. Finally, after its usage, product and package should be separately collected, keeping the circulation of high-quality materials. 
Table 2. The classification of studies into elements and categories describing circularity.

\begin{tabular}{|c|c|c|}
\hline Categories & Elements & Authors \\
\hline \multirow{8}{*}{ 1. Waste minimisation } & Waste management & {$[2,9,10,13,14,16-23,25,28,29,34-37,39-43,45,50,51,55,57,59,60,63,65-71]$} \\
\hline & Waste priority hierarchy & {$[2,14,24,28,29,45,49,51,53,55,64,71]$} \\
\hline & Waste reduction & {$[18,20,24,27,38,40,41,53,64,69-71]$} \\
\hline & Waste recycling & {$[5,8,10,13,18,25,27,29,35-37,41,51,61,63,66,72]$} \\
\hline & Zero waste concept & {$[5,6,9,17,18,20,21,25,30,34,39,48,55,61,65]$} \\
\hline & Waste streams & {$[13,24,26,40,42,48,56]$} \\
\hline & Municipal waste & {$[2,10,13,16,18,19,22,25,27-30,35,45,60,62,67,71]$} \\
\hline & Industrial waste & {$[10,13,18,20,21,37,55,60,63,66,69]$} \\
\hline \multirow{4}{*}{ 2. Resource recovery } & Macro, meso, micro level & {$[6,7,9,10,12-14,17,18,27,35,51,56,59,61,64,72]$} \\
\hline & Resource-centred dimension & {$[6,9,15,17,20,24,25,27,28,34,38-40,43,48,50,56,58,66,69,72,73]$} \\
\hline & Resource recovery & {$[2,3,5,6,8,9,13,14,16-20,22,25,27,29,30,37,39,43,45,48-50,55,58,66,74]$} \\
\hline & Savings of natural resources & {$[9,10,15,17,23,27,34,39,40,48,53,55,56,58-61,64,65]$} \\
\hline \multirow{7}{*}{ 3. Material circularity } & Material circularity, & {$[3,5,6,9,13,15,18,22,25,34,37,40,43,44,55,60,64,73]$} \\
\hline & End-of-life concept & {$[3,6,9,10,13,17,18,20,23-25,28,30,34,35,40,42,44,51,53,60,64,65]$} \\
\hline & Reutilising materials & {$[6,61,74]$} \\
\hline & Remanufacturing materials & {$[5,8,9,15,20,22,25,30,40,44,53,69]$} \\
\hline & Recycling materials & {$[2,3,7-9,13,17-22,27-30,35,37,42,45,48-50,55,61,63,66,68,70-72]$} \\
\hline & Industry-specific cycles & {$[9,20,36,53]$} \\
\hline & Technical-biological cycles & {$[9,28,35,37,65]$} \\
\hline \multirow{4}{*}{ 4. General topics } & Circular business model & {$[6,7,9,10,13,15,17,19,20,24,25,34-36,44,54,56,60,61,68,69]$} \\
\hline & Value added approach & {$[2,3,6,9,16-18,21,25,27,30,38,44,48,51,54,56,59,69,71,73-75]$} \\
\hline & Sustainability approach & {$[9,10,17,21,24,34,36,39,41,43,53,58,60,63,64,66,68]$} \\
\hline & Environmental approach & {$[9,18,24-26,34,36,42,65,66]$} \\
\hline
\end{tabular}

Table 2 indicates that authors are less concerned with evaluating recycling and composting options to manage waste and assessing waste quality playing an essential role in circularity, starting with waste minimisation, covering the recovery of resources and ending with the circularity of material. The selected categories reflect the novelty of this article.

\section{Materials and Methodology}

Circularity is quite a complex and developing process [69]. This complexity is also evident in Table 2. Therefore, this study aims to identify priorities and managerial aspects important for circularity and revise real situations, helping figure out the effective actions important for decision making.

Decisions are made by applying different factors, such as:

- The infrastructure important for circularity;

- The revision of management priorities;

- The analysis of current situations and correction of actions.

The authors divided the review of circularity options into two layers and provided theoretical and practical revision under Table 3. 
Table 3. The two-layer methodology supporting the review of circularity options.

\begin{tabular}{|c|c|c|c|c|}
\hline The Layers for Review & $\begin{array}{l}\text { Relation with } \\
\text { Circularity }\end{array}$ & $\begin{array}{l}\text { Description of Elements } \\
\text { by Stages }\end{array}$ & $\begin{array}{l}\text { Methodological } \\
\text { Background }\end{array}$ & Output \\
\hline $\begin{array}{l}\text { The background of } \\
\text { circularity }[70,71]\end{array}$ & $\begin{array}{l}\text { The cycle is covering } \\
\text { stages from (1) the } \\
\text { production of products, } \\
\text { (2) consumption by } \\
\text { households and } \\
\text { industries, (3) to the } \\
\text { management of waste, } \\
\text { (4) the distribution of } \\
\text { raw materials to the } \\
\text { secondary market, and } \\
\text { (5) provision of } \\
\text { high-quality materials } \\
\text { to primary market. }\end{array}$ & $\begin{array}{ll}\text { - } & \text { Smarter production } \\
\text { - } & \text { End-of-life extension } \\
\text { - } & \text { Management of waste } \\
\text { - } & \text { Resource recovery } \\
\text { - } & \text { Application and } \\
& \text { circulation of } \\
\text { materials }\end{array}$ & $\begin{array}{l}\text { - } \\
\text { - Classification of } \\
\text { studies into the } \\
\text { categories and the } \\
\text { review of critical } \\
\text { elements. }\end{array}$ & $\begin{array}{l}\text { Supporting and } \\
\text { indicating } \\
\text { conditions that } \\
\text { are different } \\
\text { from linearity } \\
\text { and focus on } \\
\text { environmental } \\
\text { sustainability. }\end{array}$ \\
\hline $\begin{array}{l}\text { The review of recycling } \\
\text { aspect in waste } \\
\text { management [72-75] }\end{array}$ & $\begin{array}{l}\text { The primary waste } \\
\text { hierarchy prioritises the } \\
\text { most effective solutions } \\
\text { for waste management. } \\
\text { Many alternatives are } \\
\text { identified, combined } \\
\text { with recycling, such as } \\
\text { re-usage, re-production, } \\
\text { repairment, etc. }\end{array}$ & $\begin{array}{ll}\text { - } & \text { Avoid surplus } \\
\text { - } & \text { Reuse surplus } \\
\text { - } & \text { Recycle different } \\
& \text { waste streams } \\
\text { - } & \text { Recover resources } \\
\text { - } & \text { Use disposal }\end{array}$ & $\begin{array}{l}\text { The revision of } \\
\text { recycling trends and } \\
\text { evaluation of } \\
\text { variables having an } \\
\text { impact on recycling } \\
\text { rate and the } \\
\text { construction of panel } \\
\text { regression equation }\end{array}$ & $\begin{array}{l}\text { The single way } \\
\text { to reduce waste } \\
\text { levels is the } \\
\text { increase of } \\
\text { recycling, } \\
\text { guaranteeing the } \\
\text { recovery of } \\
\text { resources. }\end{array}$ \\
\hline
\end{tabular}

Below the authors provided practical research of real situations covering the revision of two elements from the first category (municipal waste and waste recycling) and waste streams, which could be separated into:

- municipal waste;

- mineral waste;

- package waste;

- biowaste;

- $\quad$ electronic waste (e-waste); and

- construction waste.

The waste streams of mineral and construction waste were not revised during empirical research due to the low amount of provided datasets for EU countries.

All indicators are used as circular economy indicators. Therefore, the revision of indicators is important for monitoring the circular economy in several topics, such as "production and consumption" and "waste management".

In a circular economy, the value of products, materials, and resources are maintained as long as possible. Therefore, the improvement of production methods and the influence of consumers to demand greener products and less packaging is linked with waste reduction.

\subsection{The Revision of Variables}

This paper seeks to revise the main factors for constructing a new regression model. The study selected data from the Eurostat database for 2000-2019 for 27 EU countries. To identify central relationships, the authors revised 13 variables and identified the significance of defined correlation. Later, variables that were statistically not significant were taken away, and the construction of the regression equation step was used only for the ones that were detected as significant. By constructing a panel regression model, the link between biowaste and municipal waste was identified as important.

In short, biowaste means biodegradable garden and park waste (e.g., branches, leaves, grass), food and kitchen waste from households, offices, restaurants, wholesalers, canteens, caterers, and retail outlets, and similar waste from food processing plants. Biowaste 
does not include forest or agricultural waste, sewage sludge, natural fabrics, paper and cardboard, or wood waste.

Furthermore, municipal solid waste means mixed and separately collected household waste, including paper and board, glass, metals, plastics, paper, biological, wood, textiles, electrical and electronic equipment, batteries and accumulators, and bulky waste, including mattresses and furniture, and waste collected from other sources where it is similar in nature or composition to household waste. Municipal waste does not include waste from manufacturing, healthcare, agriculture, forestry, fishing, septic tanks, sewage and sewage treatment waste, including sewage sludge, end-of-life vehicles, and construction waste.

In the article, the authors analyse various types of waste and their composition, including the level of waste recycling. However, the regression equation is most pronounced between municipal waste and biowaste recycling.

The authors of this paper applied the panel regression model, which was first applied by Petris et al. [76]. The first step under the model construction procedure was the transformation of time series, helping to identify the dependent variable and its links with the regressors. Thus, the constructed model meets the requirements important for constructing a simple regression model but presents dynamic interlinks.

Such analysis presents trends (Figure 2) which show that in a 19-year period, the recycling rate of biowaste increased from 10 per cent to 17 per cent comparing to waste generation figures.

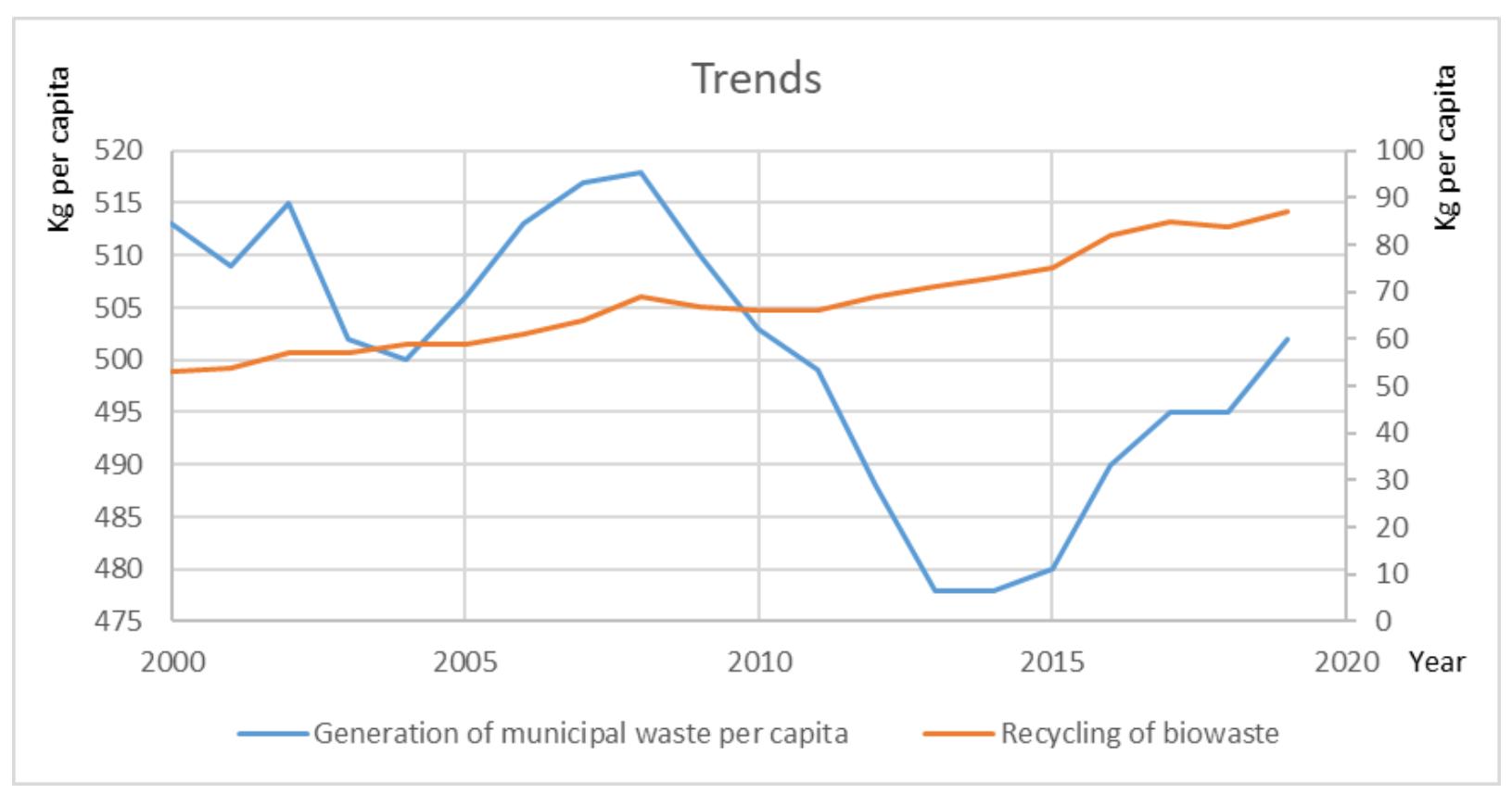

Figure 2. Revision of trends: the generated waste and the recycled biowaste.

During further analysis, we figured out the links and their strength in data pairs. For the dependent variable, the authors took the recycling of biowaste and evaluated how the changes of other variables influence it. The regressors used for the regression model are provided below:

$$
\text { rec_biow }{ }_{t}=\beta_{0}+\beta_{1} r e c \_m u_{(t-n)}+u_{t}
$$

where $r e c_{-}$biow $_{t}-$ logarithmic dependent variable of the recycling of biowaste (i.e., the ratio of composted municipal waste which is expressed in kg per capita) in year $t$;

$\beta_{0}$-intercept;

rec_mu $u_{(t-n)}$ - $\mathrm{d} \log$ of recycling rate of municipal waste, which is expressed in $\mathrm{kg}$ per capita, in year $t-n$;

$u_{t}$-random model error; and 
$\beta_{1}$-coefficient of elasticity, reflecting the impact of regressors on the recycling of biowaste.

The results of the analysis are presented in the next sub-section.

\subsection{Results of the Analysis}

The data for dependent and independent variables were normalised by applying a logarithmic procedure. Finally, the constructed regression model has its graphical representations, which is provided in Figure 3.

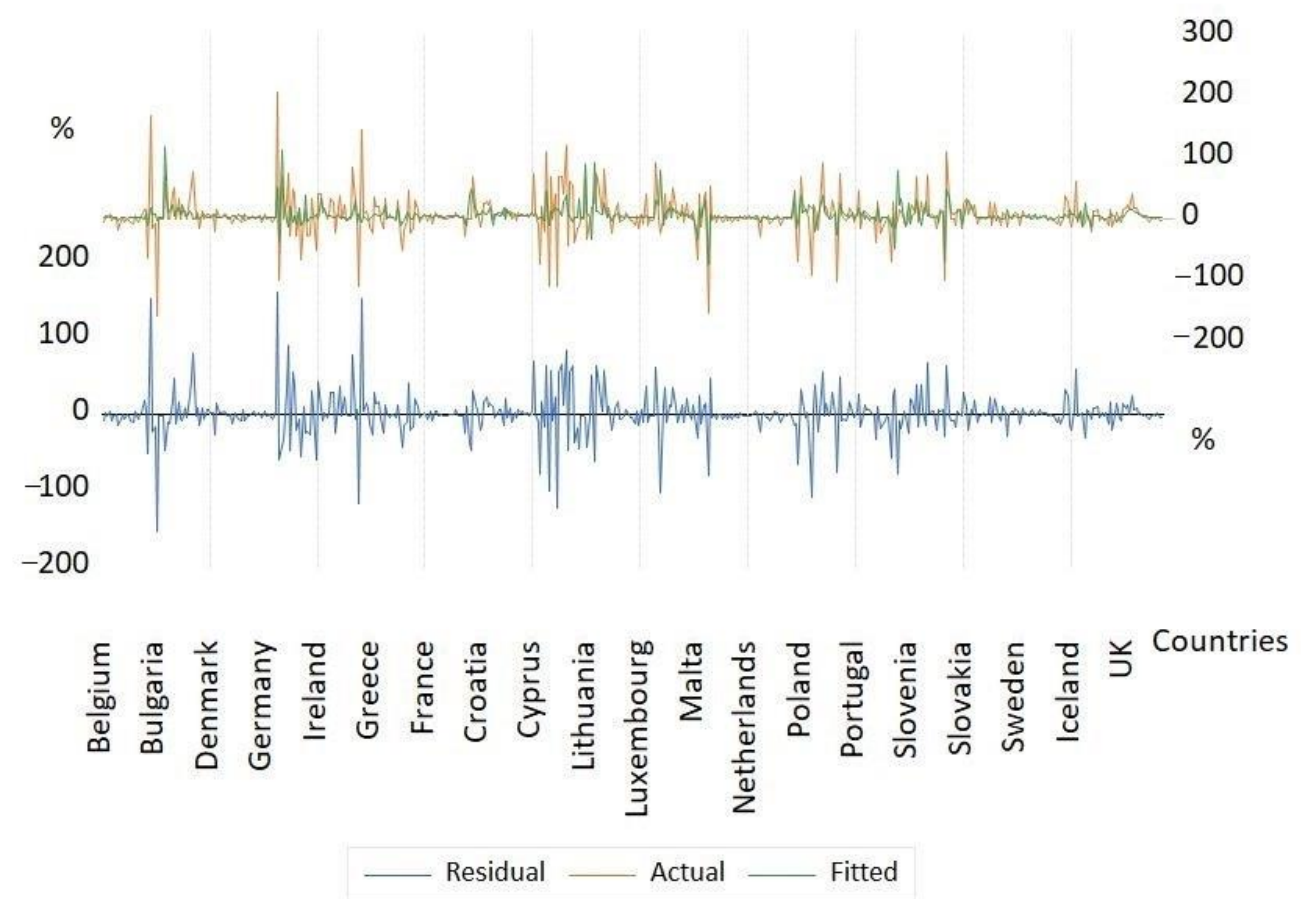

Figure 3. Forecasting the recycling of biowaste.

The regression model delivers such results:

$$
\begin{aligned}
\text { rec_biow }_{t}= & 0.028+0.6 r e c \_m u_{(t)} \\
(0.013) & (0.056)
\end{aligned}
$$

The article presents the tests of statistical validity delivered under the Hausman test. Detailed results of these statistics are provided below in Appendix A.

The authors indicated that the recycling rate of municipal waste impacts the recycling of biowaste. The increase of recycling of municipal waste by one per cent means the increase of the recycling of biowaste by 0.6 per cent. The close link between biowaste and municipal waste is explained as around 80 per cent of municipal waste consists of organic materials in nature [77]. Even electronic equipment, which is part of municipal waste, includes non-metallic components that were recently used for fuel production after being separated from other spare parts. On average, 70 per cent of materials used in electronics can be reused in other products. The same applies with paper waste, mostly cellulose [77], which could be recycled into biowaste. Fast recycling has a substantial advantage against cases where recycling is taking longer as it helps save natural resources and reduce pollution.

\section{Discussion}

The improvement of circularity is significant under various levels: society, industry, and government. However, the implementation of high-level circularity is too optimistic as recycling takes only one-fifth of generated waste. 
According to the waste priority hierarchy, waste prevention could help dispose of waste at the source, save natural resources and energy, and deliver costs. Further on, the hierarchical approach includes waste reduction, recycling, energy recovery, treatment, and ultimately disposal.

Waste reduction means using resource reduction and/or environmentally sound recycling methods before energy is recovered, recovered, treated, or disposed of and helps achieve a sustainable future. The reduction does not include waste treatment, i.e., any process designed to change the physical, chemical, or biological composition of waste.

The implementation of waste reduction activities is the most appropriate for various circular approaches and waste streams, such as applying more intelligent production. Further evaluation of recycling and composting options could be considered for managing unavoidable waste and could increase material circularity. Recycling helps protect the environment by saving energy, reducing pollution, reducing costs, and conserving natural resources. The results of the study are essential for policymakers as increased circularity leads to environmental sustainability.

Waste recycling saves energy, improves circularity, and supports the supplies of raw materials to produce new products. When it is not possible to avoid waste, recycling is the next best option. Recycling helps to prolong the life of landfills and is the best use of natural resources. Biowaste or composted waste is the recycling of organic matter. Organic matter, such as packing and non-metal waste, is transformed into a valuable soil replacement and guarantees organic waste removal from landfills. In addition, organic matter speeds up the recycling process and studies show that it is possible to perform recycling, in most cases, faster than one calendar year.

The research indicated theoretical and practical gaps in which minimisation could increase circularity and faster transformation.

The research has some limitations and does not cover the revision of construction and decomposition waste and mineral waste streams and the avoidance of surplus. However, the high-level circularity could be reached in the long-term period as the current recycling of waste is less than 20 per cent and needs to be sped up.

\section{Conclusions}

In recent years, many studies have focused on circularity. However, the attention to all circular approaches is behind: only 7 studies out of 65 cover all circular approaches. Moreover, the attention to circular approaches related to smarter production is still small, as well as to single repurpose approaches from the end-of-life extension approaches. Therefore, the application of materials approaches is highly researched by authors and appears in studies as early as 2012.

The authors indicated key elements important for reaching high-level circularity. These elements are indicated during the revision of studies. These elements have been classified into four categories-waste minimisation, resource recovery, material circularity, and general topics. The elements such as waste management, resource recovery, recycling materials, and value-added approach are the most interesting topics for studies.

For the revision of circularity as a complex process, the authors suggested a two-layer methodology, which covers theoretical and practical investigations. The practical investigations were provided during empirical research conducted for 20 years in 27 European Union countries. The paper researched trends and identified waste streams impacting biowaste available for recycling increase and figured out that municipal waste stream plays an important role. Municipal waste has an impact during the same period. The author constructed the panel regression equation and proved its statistical validity.

The future works could extend delivered study into some directions such as

- the revision of circularity measures and interlinks to show gaps;

- the involvement of other waste streams into empirical research;

- the review of waste management aspects by sectors; and

- the prognosis of recycling rates. 
The research extends the knowledge important for reaching higher circularity.

Author Contributions: Literature review and data analysis-O.L.; conceptualisation and methodology -A.B. Both authors have read and agreed to the published version of the manuscript.

Funding: This research received no external funding.

Data Availability Statement: Not applicable.

Conflicts of Interest: The authors declare no conflict of interest.

\section{Appendix A}

Table A1. Matrix of variables.

\begin{tabular}{|c|c|c|c|c|c|}
\hline \multicolumn{2}{|c|}{$\begin{array}{c}\text { Balanced Sample } \\
\text { (Listwise Missing Value Deletion) }\end{array}$} & \multirow{2}{*}{$\begin{array}{c}\text { The Recycling } \\
\text { Rate of Biowaste } \\
\text { DLOG(REC_BIOW) }\end{array}$} & \multirow{2}{*}{$\begin{array}{l}\text { The Recycling } \\
\text { Rate of Electronic } \\
\text { Waste (E-Waste) }\end{array}$} & \multirow{2}{*}{$\begin{array}{c}\begin{array}{c}\text { The Recycling } \\
\text { Rate of } \\
\text { Municipal Waste }\end{array} \\
\text { DLOG(REC_MU) }\end{array}$} & \multirow{2}{*}{$\begin{array}{c}\text { The Recycling } \\
\text { Rate of Packaging } \\
\text { Waste by Type } \\
\text { of Packaging }\end{array}$} \\
\hline & & & & & \\
\hline \multirow{2}{*}{ DLOG(REC_BIOW) } & Correlation & 1 & & & \\
\hline & Probability & - & & & \\
\hline \multirow{2}{*}{ DLOG(REC_EW(-1)) } & Correlation & 0.102355 & 0.100917 & & \\
\hline & Probability & 0.5297 & 0.5355 & & \\
\hline \multirow{2}{*}{ DLOG(REC_MU) } & Correlation & 0.862335 & -0.179613 & 1 & \\
\hline & Probability & 0 & 0.2674 & - & \\
\hline \multirow{2}{*}{ DLOG(REC_MU(-1)) } & Correlation & 0.265347 & 0.317882 & 0.386676 & \\
\hline & Probability & 0.098 & 0.0456 & 0.0137 & \\
\hline \multirow{2}{*}{ DLOG(REC_MU(-2)) } & Correlation & 0.376968 & 0.05477 & 0.15527 & \\
\hline & Probability & 0.0165 & 0.7371 & 0.3387 & \\
\hline \multirow{2}{*}{ DLOG(REC_PCW) } & Correlation & 0.362384 & -0.073196 & 0.544935 & 1 \\
\hline & Probability & 0.0216 & 0.6535 & 0.0003 & - \\
\hline \multirow{2}{*}{ DLOG(REC_PCW(-1)) } & Correlation & -0.150284 & 0.171152 & -0.062798 & -0.249102 \\
\hline & Probability & 0.3546 & 0.291 & 0.7003 & 0.1211 \\
\hline
\end{tabular}




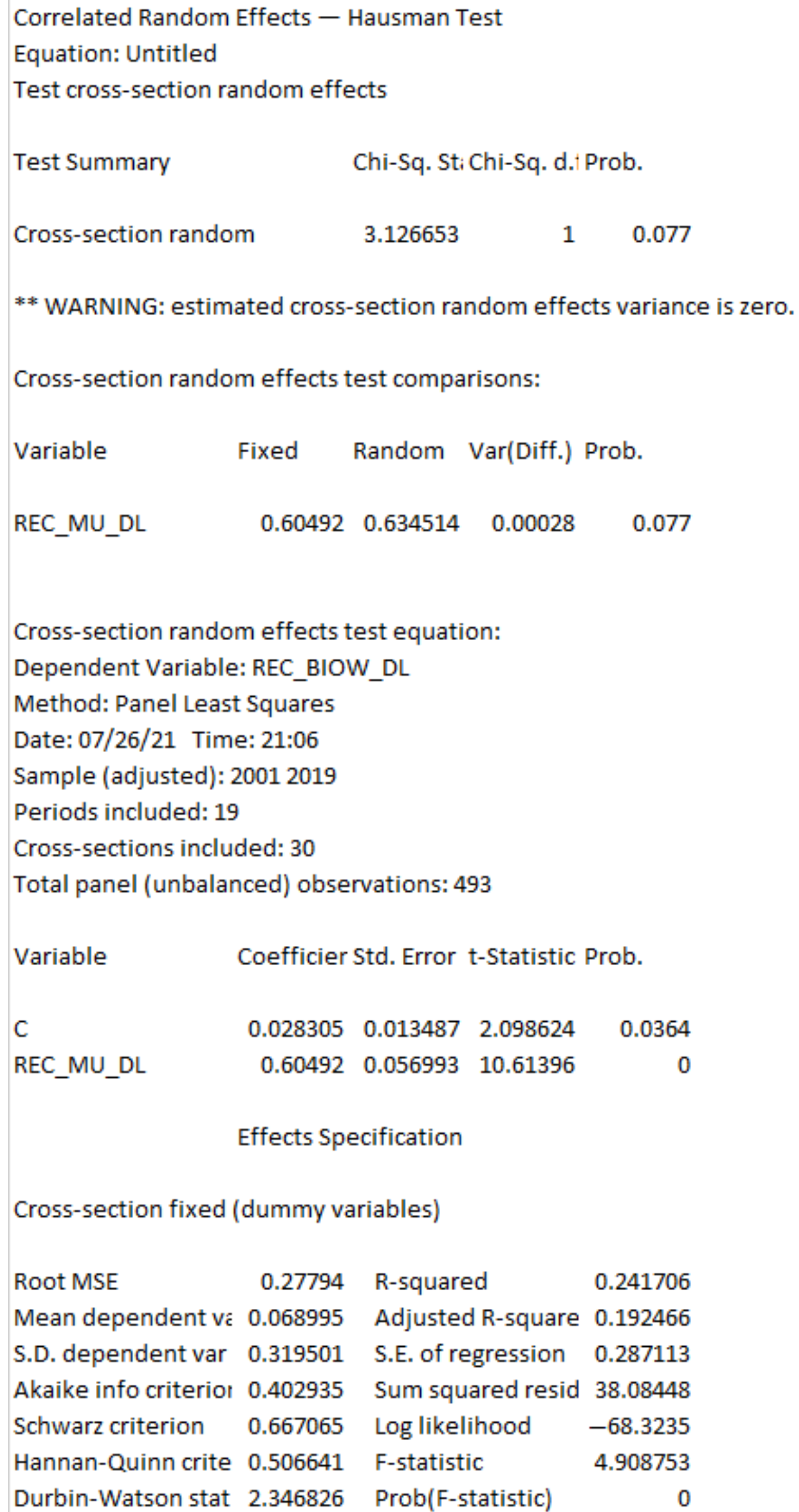

Figure A1. Formation of Equation (2), Hausman test. 


\section{References}

1. Carton, G.; Parigot, J. Disappearing natural resources: What flowers tell us about new value chains. J. Bus. Strategy 2021, 244-254. [CrossRef]

2. Wiebe, K.S.; Montt, G.; Simas, M.S.; Wood, R. Global Circular Economy Scenario in a Multiregional Input-Output Framework. J. Ind. Ecol. 2019, 24, 1192-1200. [CrossRef]

3. Araujo-Andrade, C.; Bugnicourt, E.; Philippet, L.; Rivera-Torres, P.; Suárez-Perales, I.; Kristensen, H.S.; Boudaoud, H.; Camargo, M. Review on the photonic techniques suitable for automatic monitoring of the composition of multi-materials wastes in view of their posterior recycling. Waste Manag. Res. 2021, 39, 631-651. [CrossRef] [PubMed]

4. Lebreton, L.; Andrady, A. Future scenarios of global plastic waste generation and disposal. Palgrave Commun. 2019, 5, 6. [CrossRef]

5. Agovino, M.; Ferrara, M.; Marchesano, K.; Garofalo, A. The separate collection of recyclable waste materials as a flywheel for the circular economy: The role of institutional quality and socio-economic factors. Econ. Polit. 2020, 37, 659-681. [CrossRef]

6. Lindgreen, E.R.; Salomone, R.; Reyes, T. A critical review of academic approaches, methods and tools to assess circular economy at the micro level. Sustainability 2020, 12, 4973. [CrossRef]

7. Cruz Sanchez, F.A.; Boudaoud, H.; Camargo, M.; Pearce, J.M. Plastic recycling in additive manufacturing: A systematic literature review and opportunities for the circular economy. J. Clean. Prod. 2020, 264, 344-346. [CrossRef]

8. Chen, J.; Wang, J.; Ni, A. Recycling and reuse of composite materials for wind turbine blades: An overview. J. Reinf. Plast. Compos. 2019, 38, 567-577. [CrossRef]

9. Kristensen, H.S.; Mosgaard, M.A. A review of micro level indicators for a circular economy-Moving away from the three dimensions of sustainability? J. Clean. Prod. 2020, 243, 24-28. [CrossRef]

10. Skawińska, E.; Zalewski, R.I. Circular Economy as a Management Model in the Paradigm of Sustainable Development. Management 2018, 22, 217-233. [CrossRef]

11. Yaduvanshi, N.R.; Myana, R.; Krishnamurthy, S. Circular economy for sustainable development in India. Indian J. Sci. Technol. 2016, 9, 1-9. [CrossRef]

12. Sauvé, S.; Bernard, S.; Sloan, P. Environmental sciences, sustainable development and circular economy: Alternative concepts for trans-disciplinary research. Environ. Dev. 2016, 17, 48-56. [CrossRef]

13. Hysa, E.; Kruja, A.; Rehman, N.U.; Laurenti, R. Circular economy innovation and environmental sustainability impact on economic growth: An integrated model for sustainable development. Sustainability 2020, 12, 4831. [CrossRef]

14. Banaite, D. Towards Circular Economy: Analysis of Indicators in the Context of Sustainable Development. Soc. Transform. Contemp. Soc. 2016, 2016, 26-28.

15. Hopkinson, P.; Zils, M.; Hawkins, P.; Roper, S. Managing a Complex Global Circular Economy Business Model: Opportunities and Challenges. Calif. Manag. Rev. 2018, 60,71-94. [CrossRef]

16. Tomaszewska, J. Polish transition towards circular economy: Materials management and implications for the construction sector. Materials 2020, 13, 5228. [CrossRef] [PubMed]

17. Saidani, M.; Yannou, B.; Leroy, Y.; Cluzel, F.; Kendall, A. A taxonomy of circular economy indicators. J. Clean. Prod. 2019, 207, 542-559. [CrossRef]

18. Ghisellini, P.; Cialani, C.; Ulgiati, S. A review on circular economy: The expected transition to a balanced interplay of environmental and economic systems. J. Clean. Prod. 2016, 114, 11-32. [CrossRef]

19. De Morais, L.H.L.; Pinto, D.C.; Cruz-Jesus, F. Circular economy engagement: Altruism, status, and cultural orientation as drivers for sustainable consumption. Sustain. Prod. Consum. 2021, 27, 523-533. [CrossRef]

20. Morseletto, P. Targets for a circular economy. Resour. Conserv. Recycl. 2020, 153, 927-931. [CrossRef]

21. Cecchin, A.; Salomone, R.; Deutz, P.; Raggi, A.; Cutaia, L. What Is in a Name? The Rising Star of the Circular Economy as a Resource-Related Concept for Sustainable Development. Circ. Econ. Sustain. 2021, 2, 78-79.

22. Civancik-Uslu, D.; Nhu, T.T.; Van Gort, B.; Kresovic, U.; Larrain, M.; Bilen, P.; Ragaert, K.; De Meester, S.; Dewulf, J.; Huysveld, S. Moving from linear to circular household plastic packaging in Belgium: Prospective life cycle assessment of mechanical and thermochemical recycling. Resour. Conserv. Recycl. 2021, 171, 105633. [CrossRef]

23. Garcés-Ayerbe, C.; Rivera-Torres, P.; Suárez-Perales, I.; La Hiz, D.I.L.D. Is it possible to change from a linear to a circular economy? An overview of opportunities and barriers for european small and medium-sized enterprise companies. Int. J. Environ. Res. Public Health 2019, 16, 851. [CrossRef] [PubMed]

24. Rahla, K.M.; Mateus, R.; Bragança, L. Selection Criteria for Building Materials and Components in Line with the Circular Economy Principles in the Built Environment-A Review of Current Trends. Infrastructures 2021, 6, 49. [CrossRef]

25. Blomsma, F.; Brennan, G. The Emergence of Circular Economy: A New Framing Around Prolonging Resource Productivity. J. Ind. Ecol. 2017, 21, 603-614. [CrossRef]

26. Chen, C.W. Clarifying rebound effects of the circular economy in the context of sustainable cities. Sustain. Cities Soc. 2021, 66, 120-122. [CrossRef]

27. Marino, A.; Pariso, P. Comparing European countries' performances in the transition towards the Circular Economy. Sci. Total Environ. 2020, 729, 138142. [CrossRef] [PubMed]

28. Christensen, T.B. Towards a circular economy in cities: Exploring local modes of governance in the transition towards a circular economy in construction and textile recycling. J. Clean. Prod. 2021, 305, 799. [CrossRef]

29. Ragossnig, A.M.; Schneider, D.R. Circular economy, recycling and end-of-waste. Waste Manag. Res. 2019, 37, 109-111. [CrossRef] 
30. Scheinberg, A.; Nesić, J.; Savain, R.; Luppi, P.; Sinnott, P.; Petean, F.; Pop, F. From collision to collaboration-Integrating informal recyclers and reuse operators in Europe: A review. Waste Manag. Res. 2016, 34, 820-839. [CrossRef]

31. Yun, B.Y.; Cho, H.M.; Kim, Y.U.; Lee, S.C.; Berardi, U.; Kim, S. Circular reutilization of coffee waste for sound absorbing panels: A perspective on material recycling. Environ. Res. 2020, 184, 9123. [CrossRef]

32. Jati, R.K.; Ardi, R. Conceptualization of Systems Dynamics Analysis on Informal Plastic Waste Management Systems in Indonesia. In Proceedings of the 3rd Asia Pacific Conference on Research in Industrial and Systems Engineering, APCORISE 2020—Depok, Online, Depok, Indonesia, 16 June 2020; pp. 203-207.

33. Liu, S.; Ma, T.; Sen Gupta, A.; Shimizu, K.; Wang, M.Z. Influence Diagnostics in Possibly Asymmetric Circular-Linear Multivariate Regression Models. Sankhya B 2017, 79, 76-93. [CrossRef]

34. Korhonen, J.; Nuur, C.; Feldmann, A.; Birkie, S.E. Circular economy as an essentially contested concept. J. Clean. Prod. 2018, 175, 544-552. [CrossRef]

35. Moraga, G.; Huysveld, S.; Mathieux, F.; Blengini, G.A.; Alaerts, L.; Van Acker, K.; De Meester, S.; Dewulf, J. Circular economy indicators: What do they measure? Resour. Conserv. Recycl. 2019, 146, 452-461. [CrossRef] [PubMed]

36. Sassanelli, C.; Rosa, P.; Rocca, R.; Terzi, S. Circular economy performance assessment methods: A systematic literature review. J. Clean. Prod. 2019, 229, 440-453. [CrossRef]

37. Salmenperä, H.; Pitkänen, K.; Kautto, P.; Saikku, L. Critical factors for enhancing the circular economy in waste management. J. Clean. Prod. 2021, 280, 958. [CrossRef]

38. Aguilar-Hernandez, G.A.; Dias Rodrigues, J.F.; Tukker, A. Macroeconomic, social and environmental impacts of a circular economy up to 2050: A meta-analysis of prospective studies. J. Clean. Prod. 2021, 278, 4421. [CrossRef]

39. Alnajem, M.; Mostafa, M.M.; ElMelegy, A.R. Mapping the first decade of circular economy research: A bibliometric network analysis. J. Ind. Prod. Eng. 2021, 38, 29-50.

40. Hartley, K.; Van Santen, R.; Kirchherr, J. Policies for transitioning towards a circular economy: Expectations from the European Union (EU). Resour. Conserv. Recycl. 2020, 155, 104634. [CrossRef]

41. Merli, R.; Preziosi, M.; Acampora, A. How do scholars approach the circular economy? A systematic literature review. J. Clean. Prod. 2018, 178, 703-722. [CrossRef]

42. Alhawari, O.; Awan, U.; Bhutta, M.K.S.; Ali Ülkü, M. Insights from circular economy literature: A review of extant definitions and unravelling paths to future research. Sustainability 2021, 13, 859. [CrossRef]

43. Claudia Peña, C.; Civit, B.; Gallego-Schmid, A.; Druckman, A.; Caldeira-Pires, A.; Weidema, B.; Mieras, E.; Wang, F.; Fava, J.; Milà i Canals, L.; et al. Using life cycle assessment to achieve a circular economy. Int. J. Life Cycle Assess. 2021, 26, 215-220. [CrossRef]

44. Meis-Harris, J.; Klemm, C.; Kaufman, S.; Curtis, J.; Borg, K.; Bragge, P. What is the role of eco-labels for a circular economy? A rapid review of the literature. J. Clean. Prod. 2021, 306, 456-461. [CrossRef]

45. Schwarz, A.E.; Ligthart, T.N.; Bizarro, D.G.; De Wild, P.; Vreugdenhil, B.; Van Harmelen, T. Plastic recycling in a circular economy; determining environmental performance through an LCA matrix model approach. Waste Manag. 2021, 121, 331-342. [CrossRef] [PubMed]

46. Geyer, R.; Jambeck, J.R.; Law, K.L. Production, use, and fate of all plastics ever made. Sci. Adv. 2017, 3, 25-29. [CrossRef]

47. Sandu, C.; Takács, E.; Suaria, G.; Borgogno, F.; Laforsch, C.; Löder, M.; Tweehuysen, G.; Florea, L. Society Role in the Reduction of Plastic Pollution. Handb. Environ. Chem. 2020, 4, 1-27.

48. Dewick, P.; Bengtsson, M.; Cohen, M.J.; Sarkis, J.; Schröder, P. Circular economy finance: Clear winner or risky proposition? J. Ind. Ecol. 2020, 24, 1192-1200. [CrossRef]

49. Grosso, M.; Rigamonti, L.; Niero, M. Circular economy, permanent materials and limitations to recycling: Where do we stand and what is the way forward? Waste Manag. Res. 2017, 35, 793-794.

50. Warrings, R.; Fellner, J. How to increase recycling rates. The case of aluminium packaging in Austria. Waste Manag. Res. 2021, 39, 53-62. [CrossRef] [PubMed]

51. Kalverkamp, M.; Raabe, T. Automotive Remanufacturing in the Circular Economy in Europe: Marketing System Challenges. J. Macromarketing 2018, 38, 112-130. [CrossRef]

52. Van Ewijk, S. Resource Efficiency and the Circular Economy: Concepts, Economic Benefits, Barriers, and Policies; UCL Institute for Sustainable Resources: London, UK, 2018.

53. Foster, G. Circular economy strategies for adaptive reuse of cultural heritage buildings to reduce environmental impacts. Resour. Conserv. Recycl. 2020, 152, 288. [CrossRef]

54. Lieder, M.; Asif, F.M.A.; Rashid, A.; Mihelič, A.; Kotnik, S. Towards circular economy implementation in manufacturing systems using a multi-method simulation approach to link design and business strategy. Int. J. Adv. Manuf. Technol. 2017, 93, 1953-1970. [CrossRef]

55. Ramakrishna, S.; Ngowi, A.; De Jager, H.; Awuzie, B.O. Emerging Industrial Revolution: Symbiosis of Industry 4.0 and Circular Economy: The Role of Universities. Sci. Technol. Soc. 2020, 25, 505-525. [CrossRef]

56. Kirchherr, J.; Reike, D.; Hekkert, M. Conceptualising the circular economy: An analysis of 114 definitions. Resour. Conserv. Recycl. 2017, 127, 221-232. [CrossRef]

57. Murray, A.; Skene, K.; Haynes, K. The Circular Economy: An Interdisciplinary Exploration of the Concept and Application in a Global Context. J. Bus. Ethic. 2017, 140, 369-380. [CrossRef] 
58. Van Keulen, M.; Kirchherr, J. The implementation of the Circular Economy: Barriers and enablers in the coffee value chain. J. Clean. Prod. 2021, 281, 288-289. [CrossRef]

59. Vogel, S. Circular HCI: Tools for Embedding Circular Thinking in Material-Driven Design. In Proceedings of the Companion Publication of the 2020 ACM Designing Interactive Systems Conference, Eindhoven, The Netherlands, 6-10 July 2020; pp. 233-237.

60. Pettersen, M.K.; Grøvlen, M.S.; Evje, N.; Radusin, T. Recyclable mono materials for packaging of fresh chicken fillets: New design for recycling in circular economy. Packag. Technol. Sci. 2020, 33, 485-498. [CrossRef]

61. Grafström, J.; Aasma, S. Breaking circular economy barriers. J. Clean. Prod. 2021, 292, 126002. [CrossRef]

62. Loginova, E.; Proskurnin, M.; Brouwers, H.J.H. Municipal solid waste incineration (MSWI) fly ash composition analysis: A case study of combined chelatant-based washing treatment efficiency. J. Environ. Manag. 2019, 235, 480-488. [CrossRef] [PubMed]

63. Czikkely, M.; Oláh, J.; Lakner, Z.; Fogarassy, C.; Popp, J. Waste water treatment with adsorptions by mushroom compost: The circular economic valuation concept for material cycles. Int. J. Eng. Bus. Manag. 2018, 10, 2780. [CrossRef]

64. Bjørnbet, M.M.; Skaar, C.; Fet, A.M.; Schulte, K.Ø. Circular economy in manufacturing companies: A review of case study literature. J. Clean. Prod. 2021, 294, 200-202. [CrossRef]

65. Ruiz-Real, J.L.; Uribe-Toril, J.; Valenciano, J.D.P.; Gázquez-Abad, J.C. Worldwide research on circular economy and environment: A bibliometric analysis. Int. J. Environ. Res. Public Health 2018, 15, 2699. [CrossRef] [PubMed]

66. Geng, Y.; Fu, J.; Sarkis, J.; Xue, B. Towards a national circular economy indicator system in China: An evaluation and critical analysis. J. Clean. Prod. 2012, 23, 216-222. [CrossRef]

67. Okorie, O.; Salonitis, K.; Charnley, F.; Moreno, M.; Turner, C.; Tiwari, A. Digitisation and the circular economy: A review of current research and future trends. Energies 2018, 11, 3009. [CrossRef]

68. Velasco-Muñoz, J.F.; Mendoza, J.M.F.; Aznar-Sánchez, J.A.; Gallego-Schmid, A. Circular economy implementation in the agricultural sector: Definition, strategies and indicators. Resour. Conserv. Recycl. 2021, 170, 24-27. [CrossRef]

69. Repp, L.; Hekkert, M.; Kirchherr, J. Circular economy-induced global employment shifts in apparel value chains: Job reduction in apparel production activities, job growth in reuse and recycling activities. Resour. Conserv. Recycl. 2021, 4, 171.

70. Fitch-Roy, O.; Benson, D.; Monciardini, D. All around the world: Assessing optimality in comparative circular economy policy packages. J. Clean. Prod. 2021, 286, 277-278. [CrossRef]

71. Lee, R.P.; Tschoepe, M.; Voss, R. Perception of chemical recycling and its role in the transition towards a circular carbon economy: A case study in Germany. Waste Manag. 2021, 125, 280-292. [CrossRef]

72. Barreiro-gen, M.; Lozano, R. How circular is the circular economy ? Analysing the implementation of circular economy in organisations. Bus. Strategy Environ. 2020, 34, 3484-3494. [CrossRef]

73. Moriguchi, Y. Organisation for Economic Cooperation and Development Working Group on Environmental Information and Outlook (OECD). Workshop on Material Flows and Related Indicators: Chair's Summary. J. Mater. Cycles Waste Manag. 2004, 9 , 112-120. [CrossRef]

74. Vanhamäki, S.; Rinkinen, S.; Manskinen, K. Adapting a circular economy in regional strategies of the European Union. Sustainability 2021, 13, 1518. [CrossRef]

75. Blömeke, S.; Rinkinen, S.; Manskinen, K.; Tschoepe, M.; Voss, R.; Mendoza, J.M.F. Recycling 4.0: An Integrated Approach towards an Advanced Circular Economy. In Proceedings of the 7th International Conference on ICT for Sustainability, Bristol, UK, 21 June 2020; pp. 66-76.

76. Petris, G.; Petrone, S.; Campagnoli, P. Dynamic linear models. In Dynamic Linear Models with R; Springer: New York, NY, USA, 2009; pp. 31-84.

77. Van Wyk, J.P. Biotechnology and the utilisation of biowaste as a resource for bioproduct development. Trends Biotechnol. 2001, 19, 172-177. [CrossRef] 